\title{
The GCC Human Rights Declaration: An Instrument of Rhetoric?
}

\author{
Mustafa El-Mumin \\ The Dickson Poon School of Law, King's College London, London, UK \\ Mustafa.el-mumin@kcl.ac.uk
}

\begin{abstract}
Despite being promulgated in 2014 by the Gulf Cooperation Council (GCC), the Gulf Declaration of Human Rights (GDHR) has received little academic attention. Khalifa Alfadhel is one scholar who has sought to engage with the declaration, citing it as a significant regional document worthy of commendation due to its reconciliation of both Islamic and international notions of human rights, a feat other comparable regional human rights documents have yet to achieve. Furthermore, Alfadhel praises the GDHR as it embodies the GCC's commitment to human rights and political reform, with the GDHR supplying the foundation for a regional customary law regime. This article questions such claims, arguing that Alfadhel has overlooked unambiguous flaws that contradict the GDHR's alleged regional promotion of human rights, ultimately undermining its supposed significance. Certainly, this article highlights how the GDHR is a rhetorical document that intrinsically negates the same rights it purports to protect.
\end{abstract}

\section{Keywords}

Gulf Cooperation Council (GCC) - Gulf Declaration of Human Rights (GDHR) - Cairo Declaration of Human Rights in Islam (CDHRI) - Universal Declaration of Human Rights (UDHR) - Saudi Arabia - Kuwait

The Gulf Cooperation Council (GCC) Human Rights Declaration, also known as the Gulf Declaration of Human Rights (GDHR), symbolises a concerted 
effort by the GCC in its pursuit of human rights. ${ }^{1}$ The GDHR has received particular attention from Khalifa Alfadhel, who argues that it is an instrument of cultural relativism, one that ought to be commended for its amicable reconciliation of Sharīah with the international human rights framework. ${ }^{2}$

The issue at hand is that the literature surrounding the GDHR is notably bereft, with Alfadhel's assessment the primary evaluation of the Declaration. However, a cursory glance at the GDHR's wording calls into question Alfadhel's reasoning that the Declaration reflects a 'regional commitment to human rights and political reform', as well as the above claim that it does not conflict with the relevant international human rights jurisprudence. ${ }^{3}$ Therefore, this article seeks to contribute to the relevant literature by critically evaluating the GDHR. As a matter of clarification, this article does not profess to claim that human rights cannot exist under Sharīah: it merely seeks to argue that the GDHR contradicts the acclaim Alfadhel ascribes to it as it is inherently flawed.

\section{The Origins of the Gulf Declaration of Human Rights}

The United Nation's Universal Declaration of Human Rights (UDHR) is undeniably the cornerstone of international human rights, celebrated as a succinct yet detailed document protecting against grave injustices across the world. ${ }^{4}$ One of its strengths is its ability to provide concrete scenarios of jus cogens, norms from which deviation is not permitted, also known as customary law or peremptory norms. ${ }^{5}$

Despite not being a formally binding treaty, better characterised as 'soft law', the UDHR is premised on the concept of universalism, i.e., that the rights it purports to protect extend to everyone without discrimination. Universalism's importance to modern human rights is vital: it ensures their validity whilst symbolising a collective ambition to make States' power more

1 Human Rights Declaration for the Member States of the Cooperation Council for the Arab States of the Gulf (GCC), adopted by the High Council in its 35th session (Doha) (9 December 2014) (hereafter GDHR).

2 Khalifa Alfadhel, 'The GCC Human Rights Declaration: An Instrumentation of Cultural Relativism', Arab Law Quarterly 31(1) (2017): 89-95.

3 Alfadhel, ibid., p. 94.

4 See generally Asbjørn Eide et al. (eds.), The Universal Declaration of Human Rights: A Commentary (Oxford: Oxford University Press, 1992).

5 Mahmoud Cherif Bassiouni, 'International Crimes: 'Jus Cogens' and 'Obligatio Erga Omnes', Law and Contemporary Problems 59(4) (1996): 63-74. 
ethical and accountable. ${ }^{6}$ As such, according to Rosalyn Higgins, international human rights are as "keenly felt by the African tribesman as by the European city-dweller'? ${ }^{7}$

This notion of universalism has attracted criticism from cultural relativists. ${ }^{8}$ Rhonda Howard and Jack Donnelly, two distinguished scholars on the topic, have noted how international human rights require a liberal political setting in order to be truly realised. ${ }^{9}$ Undeniably, international human rights are underpinned by individualism, an ideal that many Asian countries have denounced as a core tenet of Western liberal democracy that holds no currency in communitarian societies or other value systems. ${ }^{10}$ As a result, regional human rights systems have developed to uphold international human rights while taking specific regional concerns into account. ${ }^{11}$

However, whilst Europe, Africa and the Americas have established continental human right mechanisms, Asia is noteworthy for lacking such a system. A major hindrance to a pan-Asian human rights system is the absence of a common shared identity between the region's 53 diverse states. As such, Dinah Shelton and Paolo Carozza suggested the continent may be better served by 'sub-regional' human rights mechanisms. ${ }^{12}$ The Association of Southeast Asian Nations is one such sub-regional system..$^{13}$ Another is the League of Arab States, also known as the Arab League, which established an Arab Court of Human Rights in 2014. ${ }^{14}$

6 Upendra Baxi, The Future of Human Rights, 3rd edn. (New Delhi: Oxford University Press, 2008), p. 185 .

7 Rosalyn Higgins, Problems and Process: International Law and How We Use It (Oxford: Clarendon Press, 1994), p. 96.

8 See generally Adamantia Pollis \& Peter Schwab, 'Human Rights: A Western Construct with Limited Applicability', in Adamantia Pollis \& Peter Schwab (eds.), Human Rights: Cultural and Ideological Perspectives (New York: Praeger, 1979).

9 Rhonda Howard \& Jack Donnelly, 'Human Dignity, Human Rights, and Political Regimes', in Jack Donnelly (ed.), Universal Human Rights in Theory and Practice, 2nd edn. (Ithaca: Cornell University Press, 2002), p. 67.

10 Lynda Bell, Andrew Nathan \& Ilan Peleg (eds.), Negotiating Culture and Human Rights (New York: Columbia University Press, 2001), p. 7.

11 See UN General Assembly, Vienna Declaration and Programme of Action (12 July 1993) UN Doc A/CONF.157/23, para. 37 .

12 Dinah Shelton \& Paolo Carozza, Regional Protection of Human Rights (Oxford: Oxford University Press, 2013), p. 90.

13 See Hao Duy Phan, 'The Evolution Towards an ASEAN Human Rights Body', Asian Pacific Journal on Human Rights and the Law 9(1) (2008): 1-12.

14 Salem Alshehri, 'An Arab Court of Human Rights: The Dream Desired', Arab Law Quarterly 3o(1) (2016): 34-52. 
The sub-region of particular interest and relevance to this article is the GCC, an intergovernmental alliance of six monarchies on the Arabian Peninsula, namely Bahrain, Saudi Arabia, Qatar, Kuwait, Oman and the United Arab Emirates (UAE). Created in 1981, the GCC was formed as a way of fostering regional unity and cohesion in economics, education and culture. ${ }^{15}$ The GCC countries not only share geographical and maritime borders but also the same values, Arabic language and Islamic religion, with the latter underpinning their legal systems by way of Sharíah. ${ }^{16}$ More recently, the region has undergone a series of political and social reform, instigated by both rulers and the general populace. ${ }^{17}$

One particularly notable event was the GCC's unanimous 2014 adoption of the GDHR, a soft-law document aimed at protecting and promoting human rights across the region. Like most regional human right declarations, the GDHR focuses on civil and political liberties as well as some economic and social rights. Encompassing 47 articles, the GDHR's preamble notes how it was inspired by the GCC States' respect for human dignity and the protection of it, as per Sharíah. Its preamble also notes that this protection of human rights is intended to continue the GCC's aims of unity and coordination. The preamble concludes by underscoring the G CC's commitment to human rights, taking into account relevant regional and international human rights agreements such as the UDHR, the Arab Charter on Human Rights and the Cairo Declaration on Human Rights in Islam (CDHRI).

\section{The GDH R: An Instrumentation of Cultural Relativism}

It is within this historical and political context that Alfadhel believes the GDHR is an effective instrument of cultural relativism that ought to be applauded. This is because it reconciles the GCC's culture and principles (primarily based on Shari`ah) with the international community's values better than any other comparable regional documents. Certainly, he argues the GDHR is a noticeable evolution in contrast to the CDHRI, another soft-law declaration, as

\footnotetext{
15 Gulf Cooperation Council Charter (adopted 25 May 1981).

16 Saudi Arabia Basic Law, 1 March 1992, Article 1; Oman Constitution, 6 November 1996, Article 2; Qatar Constitution, 9 April 2004, Article 1; Constitution of the Kingdom of Bahrain, 14 April 2002, Article 2; United Arab Emirates Constitution, 2 December 1971, Article 7; Kuwait Constitution, 11 November 1992, Article 2.

17 See generally David Held \& Kristian Ulrichsen (eds.), The Transformation of the Gulf: Politics, Economics and the Global Order (New York: Routledge, 2013).
} 
the former does not provide an escape from the universality of human rights. ${ }^{18}$ Reference to the CDHRI does seem to substantiate this claim.

The CDHRI was adopted in 1990 by the Organisation of Islamic Cooperation, to which all the GCC States are a party. Arguably the Muslim world's answer to the UDHR, the CDHRI reaffirms human dignity as the basis of human rights. However, unlike the UDHR, the CDHRI preamble notes that Islam is the foundation for such rights. ${ }^{19}$ Constant references to Islam within the CDHRI is an important theme, with more than one-half of the Declaration's provisions citing Sharīah or Islamic principles. The numerous allusions to Sharīah, as well as the wording of certain articles, has led some scholars to heavily critique the CDHRI, claiming it dilutes the effective protection of international civil and political rights. ${ }^{20}$

As such, prima facie, Alfadhel's argument that the GDHR better reconciles Sharī'ah with international human rights has some merit. Unmistakably, while UD HR Article 18 protects the right to freedom of belief, this right is non-existent under the CDHRI, with the closest provision being CDHRI Article 10, which does nothing more than prohibit conversion from Islam. GDHR Article 6while not identical to UDHR Article 18-better protects the freedom of belief, providing a minimum standard for its necessary protection.

This reconciliatory attempt is also apparent in the right to freedom of association, protected internationally by UDHR Article 20. It is also protected under Sharíah, as Islam generally permits individuals to organise themselves if their cooperation is to pursue legitimate interests, as opposed to sinful purposes. ${ }^{21}$ However, there is a remarkable lack of protection of this right under the CDHRI's framework. On the other hand, GDHR Article 31 offers a middle ground, proclaiming that 'Every person has the freedom to form associations, assemblies and unions, subject to the provisions of the regulation (law)'. Therefore, the GDHR contradicts neither Sharīah nor the UDHR, lending further credibility to Alfadhel's aforementioned claims.

18 Alfadhel, supra note 2 at 95. Organisation of the Islamic Conference (OIC), Cairo Declaration on Human Rights in Islam, 5 August 1990 (hereafter CDHRI).

19 CDHRI, ibid., Article 1.

20 Ann Elizabeth Mayer, Islam and Human Rights: Tradition and Politics, 3rd edn. (Boulder, CO: Westview Press, 2006), p. 76.

21 Qur'ān, 5:2. See further Mohammad Hashim Kamali, Freedom of Expression in Islam (Cambridge: Cambridge University Press, 1997). 
The above discussion illustrates that there is some strength to Alfadhel's assertion that the GDHR is an evolution from the CDHRI. Definitely, the GDHR fills in gaps that the CDHRI ignored, providing explicit protection of fundamental freedoms. However, deeper analysis reveals that the GDHR negates any practical defence of the rights it purports to protect owing to two major and inherent shortcomings Alfadhel overlooked.

\subsection{The Interpretation of Shariah}

The first issue with Alfadhel's characterisation of the GDHR is his claim that the interpretation of Shar'`ah between the GDHR and CDHRI is different. Certainly, Alfadhel posits that, although the GDHR affirms a number of Islamic principles, these affirmations are derived from a liberal interpretation of Sharīah, as opposed to a more conservative approach as seen under the CDHRI. ${ }^{22}$ It is this supposedly liberal interpretation that allows the GDHR to not only openly protect fundamental rights which the CD HRI neglects but also offer protection in line with comparable international documents.

Whilst it is conceded that the GDHR is more explicit in its protection of fundamental freedoms, Alfadhel is mistaken in referring to this pronounced protection as a liberal interpretation of Sharīah. Despite being anchored by the Qur'ān and Sunnah as primary sources, different Islamic schools of thought determine what Shari'ah prescribes, with both the GDHR and CDH RI notably lacking reference to any particular school of thought. ${ }^{23}$ Therefore, the interpretation of either declaration depends on a Muslim state's own interpretation of Sharīah.

For example, Saudi Arabia is known for utilising a literal and 'ultraconservative' Wahhabi doctrine for their entire legal system. ${ }^{24}$ On the other hand, Kuwait's legal system is an amalgamation of common law, civil law and Sharīah, with Sharī‘ah premised on the comparatively less conservative Mālikī interpretation, which in turn is used predominately for personal status laws. ${ }^{25}$ Consequently, Saudi Arabia's interpretation of a given human right under

\footnotetext{
22 Alfadhel, supra note 2 at 91.

23 For an explanation of the sources of Sharīah, see Fazlur Rahman, Islam, 2nd edn. (Chicago: University of Chicago Press, 1979), pp. 53-54.

24 For more on the relationship between Wahhabism and Saudi Arabia, see David Commins, The Wahhabi Mission and Saudi Arabia (New York: I.B. Tauris, 2009).

25 Sean Foley, 'Kuwait, Qatar, the UAE, Bahrain and Oman', in Barry Rubin (ed.), Guide to Islamist Movements Vol. II (New York: M.E. Sharpe, 2009), p. 305.
} 
Islam, and its following protection, may be in a manner completely unlike that of Kuwait's.

This is best demonstrated with reference to a fundamental freedom protected under both declarations. GDHR Article 9 and CDHRI Article 22 mirror each other, safeguarding the right to freedom of expression insofar as the right does not contradict Sharíah. In this sense, the GDHR and CDHRI's protection of the freedom of expression is interchangeable. Yet, due to the fact that the protection of such a right is dependent on Sharīah, the net effect of its domestic protection is arguably the same regardless of whichever document is used. Saudi Arabia provides no tangible regard to the freedom of expression, routinely imprisoning political dissenters and social campaigners. ${ }^{26}$ Inversely, Kuwait is more tolerant, providing constitutional protection to the freedom of expression due to its comparably more liberal interpretation of Sharīah and its limited influence in society and politics. ${ }^{27}$

Therefore, Afladhel conflates the GDHR's terminology and explicit protection of certain fundamental freedoms with a liberal interpretation of Sharīah. This is evidently not the case: the GDHR is no more religiously liberal than the CDHRI as both are ultimately open to spiritual interpretation. ${ }^{28}$ As such, the protection of fundamentals freedoms is placed in the domain of a country's specific Islamic interpretation of such a right, regardless as to whether the GDHR explicitly protects it or not.

\subsection{Deferment to Domestic Law}

The second flaw with the GDHR, which Alfadhel entirely disregarded, is the fact that many of the freedoms it protects have an additional caveat that requires such protection to be in accordance with domestic law. This in turn contravenes any actual protection, let alone promotion, of these rights when the relevant GCC legislation is studied.

Revisiting the above discussion on the GDHR's protection of the right to freedom of association underscores this argument. As noted, GDHR Article 31 allows every person the right to freedom of association, unlike the CDHRI. This right is historically linked with trade unions, generally considered imperative

26 Patrick Wintour, 'UN accuses Saudi Arabia of using terror laws to suppress free speech', The Guardian, 4 May 2017, available at: https://www.theguardian.com/world/2017/ may/04/un-accuses-saudi-arabia-of-using-terror-laws-to-suppress-free-speech, accessed 14 April 2019.

27 Kuwait Constitution, 11 November 1962, Article 36.

28 GDHR, Article 44. 
in the protection of 'unorganized and vulnerable' employees. ${ }^{29}$ Following that, trade unions are arguably reconcilable with Sharīah as they seek to pursue the accepted Islamic principle of promoting humanity. ${ }^{30}$ GDHR Article 31 even overtly includes the freedom to form 'unions'. So far, and as discussed above, Alfadhel's argument is reasonable: the GDHR protects the right to association, reconciling Sharīah, (which the CDHRI failed to do), with international standards.

However, the GDHR Article 31's caveat about protecting such a right 'subject to the provisions of the regulation (law)' ironically denies it protection. Saudi Arabia and the UAE prohibit trade unions as categorically unlawful. ${ }^{31}$ Qatar and Kuwait only permit their respective nationals access to trade unions, denying the notion that 'every person' has access to freedom of association. ${ }^{32}$ Additionally, whilst Bahrain and Oman's labour law place no express restrictions on the right, the reality is that trade unions have little ability to protect their interests. For example, Oman's labour law heavily dilutes trade union's powers, requiring excessively long notice periods of 3 weeks for any proposed strikes. ${ }^{33}$

The GCC States' varied legislative attitudes to the freedom of movement further emphasise the GDHR's futility. Unquestionably, GDHR Article 10 states that 'Freedom of movement, residence and departure is a right of every human being according to the regulations (law)'. This provision is essentially empty, particularly when the region's infamous Kafala system is taken into account. The Kafala is the GCC's unique form of labour regulation, whereby a migrant worker needs the sponsorship of a GCC party in order to enter and work in that respective GCC state. ${ }^{34}$ It is structured through a variety of legislation, including residency, immigration and labour laws. ${ }^{35}$

29 See generally Geraldo von Potobsky, 'Freedom of Association: the Impact of Convention No. 87 and ILO Action', International Labour Review 137(2) (1998): 195-221.

30 Qur'ān, 58:9-10; Kamali, supra note 21 at 86.

31 Saudi Arabia Labour and Workmen Law, Royal Decree No. M/21 (15 November 1969), Articles 210-228; UAE Federal Law No. 8 of 1980 on Regulation of Labour Relations, Articles $154-165$.

32 Qatar Law No. 14 of 2004 Regulating Employment, Article 116; Kuwait Law No. 6 of 2010 Promulgating the Law of Labour in the Private Sector, Article 99.

33 Oman Ministerial Decree 17 of 2007 amending Ministerial Decree No. 294/2006 on Regulation of Collective Bargaining, Peaceful Strikes and Closure, Article 19 and Article 23.

34 See generally Hanan Malaeb, 'The "Kafala” System and Human Rights:Time for a Decision', Arab Law Quarterly 29(4) (2015): 307-342.

35 Bahrain Aliens Immigration and Residence Act of 1965; UAE Federal Law No. 6 of 1973 Regarding the Entry and Residence of Foreigners; Kuwait Aliens' Residence Law of 1959; 
The continued use of the Kafala flagrantly denies freedom of movement through many ways. First and foremost, migrant workers-due to their ability to work being tied to a sponsor-require a Non-Objection Certificate (NOC) in order to legally switch jobs. These Nocs are notoriously withheld to prevent employees from moving to other companies, whether domestically or abroad. Furthermore, Saudi Arabia wholly precludes migrant workers from leaving the state, regardless of the reason, unless they have an 'exit permit' granted by their sponsors. ${ }^{36}$ These forms of legislative restrictions are used as a form of punishment to keep a migrant within the state, denying their freedom of movement. They are applied in practice to all parts of the GCC migrant workforce, from domestic workers to white-collar executives and even sport stars. ${ }^{37}$

This caveat requiring protection to correlate with domestic legislation is not only limited to the freedoms of association and movement: it also extends to the GDHR's treatment of the freedom of belief (GDHR Article 6), freedom of opinion and expression (GDHR Article 9) and the right to political participation (GDHR Article 30). Essentially, this simple device permits-and justifies-the GCC States' limitation of civil and political liberties considered to be of the highest importance by the international community. ${ }^{38}$ As such, this obvious flaw within the GDHR entirely refutes Alfadhel's claims that the declaration is an object of political reform which does not contradict international human rights jurisprudence.

In conclusion, despite what Alfadhel alleges, the GDHR does not indicate a substantive 'regional commitment to human rights and political reform'. On the contrary, the GDHR arguably solidifies the GCC status quo, justifying the protection (or lack thereof) of fundamental freedoms. It does this by utilising baseless rhetoric and circumventive means that allows the GCC States to not only formulate, but also regulate their own understanding of a right, regardless

Oman Foreign Residency Law No. 16 of 1995; Qatar Law No. 21 of 2015 Detailing the Regulations on the Entry, Exit, and Residency of Foreign Nationals.

36 Saudi Arabia Residence Regulations, Law No. 17/2/25/1337 (amended), Article 16.

37 Owen Gibson, 'French footballer trapped in Qatar asks Guardiola and Zidane for help', The Guardian, 14 November 2013, available at: https://www.theguardian.com/football/ 2013/nov/14/zahir-belounis-letter-pep-guardiola-zinedine-zidane-qatar-trapped, accessed 14 April 2019.

38 See further Ilias Bantekas \& Lutz Oette, International Human Rights: Law and Practice, 2nd edn. (Cambridge: Cambridge University Press, 2016), p. 390. 
of whether that understanding correlates with either international or Islamic standards.

Whilst it is admitted that the GDHR is more explicit in its protection of fundamental rights, taking into account basic freedoms that the CDHRI spectacularly failed to acknowledge, Alfadhel misconstrues the former's use of language (that is especially attuned with international human rights documents), as a liberal interpretation of Sharīah. Indeed, the fact that the GDHR is underpinned by Shari`ah allows the GCC States, with their differing adherence and application of various schools of Islamic thought, to interpret particular fundamental freedoms as they see fit, and protect them accordingly.

Likewise, the GDHR's references to the protection of certain rights in accordance with relevant domestic legislation further justifies the GCC's States discretionary treatment of certain human rights. This places further doubt on Alfadhel's argument that the GDHR merges international and Islamic human rights, particularly when it is noted that this alarming caveat applies to some of the freedoms considered most integral to the international community.

Ultimately, although the GDHR is a soft-law document, Alfadhel's assertion that it presents a genuine attempt at a regional commitment to human rights is misplaced. Perhaps the clearest proof that the GDHR does not change the region's political landscape is the notable absence of region-wide change to bring domestic legislation in line with the supposedly liberal GDHR subsequent to its promulgation. Irrefutably, the Kafala system has not been abolished and political dissenters exercising their freedom of speech, under both Islamic and international understandings of the right, are routinely imprisoned across the region. As such, the GDHR is a hollow and rhetorical regional document, wholly undeserving of any substantive praise. 